\begin{tabular}{|l|l|l||}
\hline \multicolumn{2}{|c|}{ PublisherInfo } \\
\hline \hline PublisherName & $:$ & BioMed Central \\
\hline \hline PublisherLocation & $:$ & London \\
\hline \hline PublisherImprintName & $:$ & BioMed Central \\
\hline \hline
\end{tabular}

\title{
Biomics Centre opens in UK
}

\begin{tabular}{|l|l|l||}
\hline \multicolumn{2}{|c|}{ ArticleInfo } \\
\hline \hline ArticleID & $:$ & 4738 \\
\hline \hline ArticleDOI & $:$ & $10.1186 /$ gb-spotlight-20030401-03 \\
\hline \hline ArticleCitationID & $:$ & spotlight-20030401-03 \\
\hline \hline ArticleSequenceNumber & $:$ & 90 \\
\hline \hline ArticleCategory & $:$ & Research news \\
\hline ArticleFirstPage & $:$ & 1 \\
\hline \hline ArticleLastPage & $:$ & 3 \\
\hline \hline & & RegistrationDate : 2003-4-1 \\
\hline ArticleHistory & $:$ & OnlineDate \\
\hline \hline ArticleCopyright & $:$ & BioMed Central Ltd2003-4-1 \\
\hline \hline ArticleGrants & $:$ & \\
\hline \hline ArticleContext & $:$ & 130594411 \\
\hline \hline
\end{tabular}


A new medical research center opens in London today (April 1) that will bring together scientists in four key areas to generate novel treatments for diseases such as cancer, heart disease and tuberculosis.

The Biomics Centre, which occupies $250 \mathrm{~m}^{2}$ of a refurbished wing of St George's Hospital Medical School, will be home to researchers in genomics and proteomics, as well as in the newer fields of metabolomics and transcriptomics.

It represents a new breed of research center that attempts to integrate publicly funded research with pharmaceutical and biotechnology interests, and apply them directly to patients' needs.

Other examples include Singapore's Biopolis project, due to be completed early next year, and Genopole in Evry, France. At Kobe in Japan, the Center for Developmental Biology (CDB), which is funded by the government research agency RIKEN, supports basic research geared towards regenerative medicine with a strong emphasis on translation to the clinic.

The UK center will support ongoing research at St George's and elsewhere with the aim of speeding up diagnosis and providing better treatments. "Our biggest strengths at St George's are in cardiovascular disease and in infectious diseases," said Tim Rutherford, the center's scientific director. "There is major research here into tuberculosis, into methicillin-resistant Staphylococcus aureus (MRSA) and into malaria."

Among the center's recruits are John Griffiths, who pioneered the application of magnetic resonance imaging and spectroscopy to cancer, and Qingbo Xu, formerly of the Austrian Academy of Sciences institute in Innsbruck, Austria, who will study abnormal heart development.

Metabolomics is the study of the body's metabolites, changes in which reflect the nature and progression of a disease, whereas transcriptomics refers to the large-scale analysis of messenger RNAs particularly those transcribed from genes that are important in disease.

The Biomics Centre, which boasts a microarray facility and equipment to analyse thousands of metabolites simultaneously, will be funded by grants from both government agencies and private charities. These include the Medical Research Council, The Wellcome Trust, the British Heart Foundation and Research into Ageing. It has already attracted around $£ 8$ million (US\$12.8 million).

"For St George's, having four -omics programmes under one roof will provide a vast amount of data with potential clinical relevance," said Doug Sipp, spokesman for the CDB in Kobe. "But as in all such undertakings, they will need to provide bridging support in the form of user-friendly bioinformatics, proactive management of administrative, regulatory and intellectual property issues, and enforced opportunities for communication and collaboration between the basic research and clinical staff."

Few doubt that there will be more such centers springing up in the near future. The National Human Genome Research Institute (NHGRI), part of the US National Institutes of Health, already combines genomics and proteomics and will be moving more towards clinical applications once the completion of 
the Human Genome Project is officially announced this month. As Geoff Spencer, a spokesman for the NHGRI put it, "The more groups the better."

\section{References}

1. St George's Hospital Medical School, [http://www.sghms.ac.uk/]

2. Genopole, [http://www.genopole.org/html/en/home/index.htm]

3. Center for Developmental Biology, [http://www.cdb.riken.go.jp/english/index.html]

4. Austrian Academy of Sciences, [http://www.oeaw.ac.at/english/home.html]

5. Medical Research Council, [http://www.mrc.ac.uk/]

6. Wellcome Trust, [http://www.wellcome.ac.uk/]

7. British Heart Foundation, [http://www.bhf.org.uk/]

8. Research into Ageing, [http://www.ageing.org/]

9. National Human Genome Research Institute, [http://www.genome.gov/] 